\title{
Target Volume Determination for Precise Radiation Therapy (RT) of Central Neurocytoma: An Original Article
}

\author{
Murat Beyzadeoglu ${ }^{1}$, Ferrat Dincoglan ${ }^{1}$, Selcuk Demiral ${ }^{1}$, Omer Sager ${ }^{1}$ \\ ${ }^{I}$ Department of Radiation Oncology; University of Health Sciences, Gulhane Medical Faculty, \\ Ankara, Turkey. \\ *Corresponding Author: Dr. Omer Sager, University of Health Sciences, Gulhane Medical Faculty, \\ Department of Radiation Oncology, Gn. Tevfik Saglam Cad. 06018, Etlik, Kecioren Ankara /Turkey
}

\begin{abstract}
Objective: Central Neurocytoma $(C N)$ is a rarely seen intracranial neoplasm. A frequent manifestation of $C N$ includes symptomatology related to increased intracranial pressure as a result of obstructive hydrocephalus. Radiation therapy (RT) may be utilized for CN to improve tumor control in selected patients. Precision in determination of the target volume is an essential component of contemporary RT. In this study, we assess the incorporation of magnetic resonance imaging (MRI) for radiation treatment planning for CNs.

Materials and Methods: Evaluation of RT target volume determination with and without incorporation of MRI has been performed. Ground truth target volume used for actual treatment and comparison purposes has been defined by the board-certified radiation oncologists after comprehensive assessment, thorough collaboration, colleague peer-review, and ultimate consensus.

Results: Target volume determination by CT-only imaging and by CT-MR fusion based imaging has been comparatively assessed for $R T$ of $C N$ in this study. Ground truth target volume defined by the boardcertified radiation oncologists after thorough evaluation, collaboration, colleague peer review and ultimate consensus has been found to be identical to target determination by use of CT-MR fusion based imaging.

Conclusion: Despite substantial advances in neurosurgical techniques, complete tumor removal may not be feasible for deeply seated lesions in selected patients with CNs. RT may play an essential role for multidisciplinary CN management. Incorporation of multimodality imaging with MRI into the radiation treatment planning process may improve the accuracy and precision in target definition for CNs, however, there is need for further studies.
\end{abstract}

Keywords: central neurocytoma $(C N)$, radiation therapy $(R T)$, magnetic resonance imaging (MRI)

\section{INTRODUCTION}

Central Neurocytoma $(\mathrm{CN})$ is a rarely seen intracranial neoplasm comprising about $0.1 \%$ to $0.5 \%$ of intracranial tumors withthe peak incidence typically between the ages of 20 to 31 years [1-3]. Most common lesion location includes the the anterior half of lateral ventricles with attachment to septum pellucidum and locations for extra ventricular neurocytoma include the frontal lobe, cerebellum, temporal lobe, and others [1-3]. Lesions arising from the third or fourth ventricles are quite uncommon [4-7].

A frequent manifestation of $\mathrm{CN}$ includes symptomatology related to increased intracranial pressure as a result of obstructive hydrocephalus. Differentiation of CNs from other brain tumors based on imaging features may be difficult which underscores the incorporation of histological markers including synaptophysin to aid in diagnosis [3]. Primary objective of management includes total tumor removal by means of gross total resection, which offers favorable prognosis with satisfactory rates of local control and survival [2,3]. However, complete surgical resection may not be feasible for management of deeply seated lesions regarding the excessive risks of surgery in selected patients and radiation therapy (RT) may be utilized for these patients to achieve improved tumor control. Utility of chemotherapy for management of $\mathrm{CN}$ merits further investigation, however, chemotherapy may be used in the recurrent and salvage settings as adjunct therapy to improve treatment outcomes [8]. Nevertheless, optimal management of $\mathrm{CNs}$ may be performed with incorporation of multimodal treatments [9].

Given that CNs may have a propensity for recurrence even after initial management with surgery, particularly when complete tumor removal is not feasible, RT in the forms of conventionally fractionated RT or radio surgery may be utilized[10-22].Contemporary RT 
technologies and radio surgery in the forms of Stereotactic Radio surgery (SRS), Stereotactic Body Radiotherapy (SBRT) and Hypofractionated Stereotactic Radiation Therapy (HFSRT) may be used for focused irradiation of several CNS disorders as well as tumors located throughout the human body with favorable therapeutic results [23-43].

Precision in determination of the target volume is an essential part of contemporary RT and particularly for radiosurgical practice given the smaller target volumes receiving significantly higher doses per fraction. Traditionally, treatment planning for radiation treatment has been based on CT-simulation images of patients acquired at the treatment position. In this study, we assess the incorporation of MRI for radiation treatment planning for CNs.

\section{Materials AND MethodS}

In this study, evaluation of RT target volume determination with and without incorporation of MRI has been performed. Ground truth target volume serving as the reference has been outlined by the board-certified radiation oncologists after detailed assessment, thorough collaboration and ultimate consensus. Informed consents have been acquired before treatment, and management with RT has been decided by the multidisciplinary collaboration of experts from neuro radiology, neurosurgery, and radiation oncology. Comprehensive assessment has been done considering lesion size, location, patient symptomatology and preferences. Patient immobilization has been performed by using a thermoplastic mask. After immobilization, planning CT images have been acquired at the CT-simulator (GE Light speed RT, GE Healthcare, Chalfont St. Giles, UK) available at our institution including the region extending from the vertex to the $2 \mathrm{~cm}$ below the cervical spine. Acquired planning CT images were sent to the contouring workstation (Sim MD, GE, UK) for delineation of treatment volumes along with surrounding normal tissues. Target volume determination for RT has been done based on the CT-simulation images only or fused CT and MR images. A comparative evaluation of target determination with $\mathrm{CT}$ only and by incorporation of CT-MR fusion has been done. Determination of ground truth target volume to be utilized for actual treatment and comparison purposes has been done by the board certified radiation oncologists after comprehensive evaluation, colleague peer review, collaboration and ultimate consensus.

\section{RESULTS}

Definition of CN target volume by use of CTonly imaging and by incorporation of CT-MR fusion based imaging has been comparatively assessed in this study for RT using the linear accelerator (LINAC). Ground truth target volume determined by the board-certified physicians after comprehensive assessment, collaboration, colleague peer review and ultimate consensus has been detected to be identical to target determination by use of CTMR fusion based imaging.

Radiation treatment planning has been performed by Precise (Elekta, UK) treatment planning system. Optimal target coverage and normal tissue sparing has been provided by incorporation of contemporary techniques. Synergy (Elekta, UK) LINAC available at our tertiary cancer center has been utilized for treatment delivery.

Figure 1 shows axial CT image of a patient with $\mathrm{CN}$, and figure 2 shows the corresponding axial MR image of the same patient with $\mathrm{CN}$.

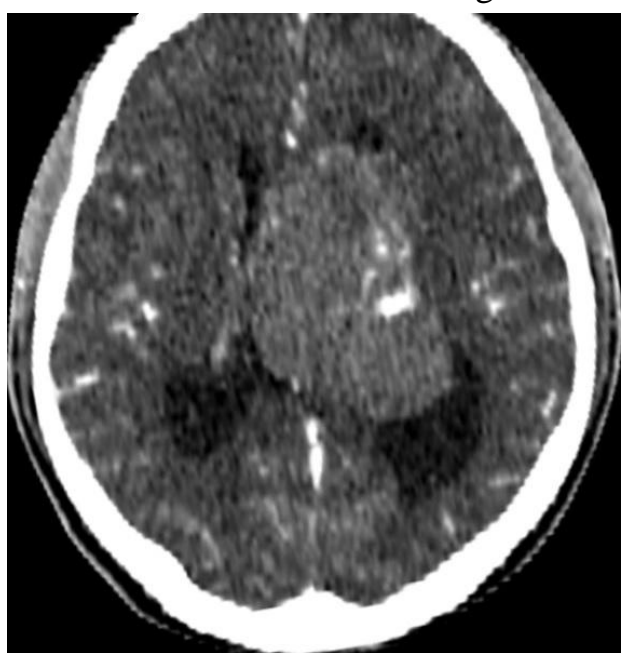

Figure1. Axial CT image of a patient with $C N$ 


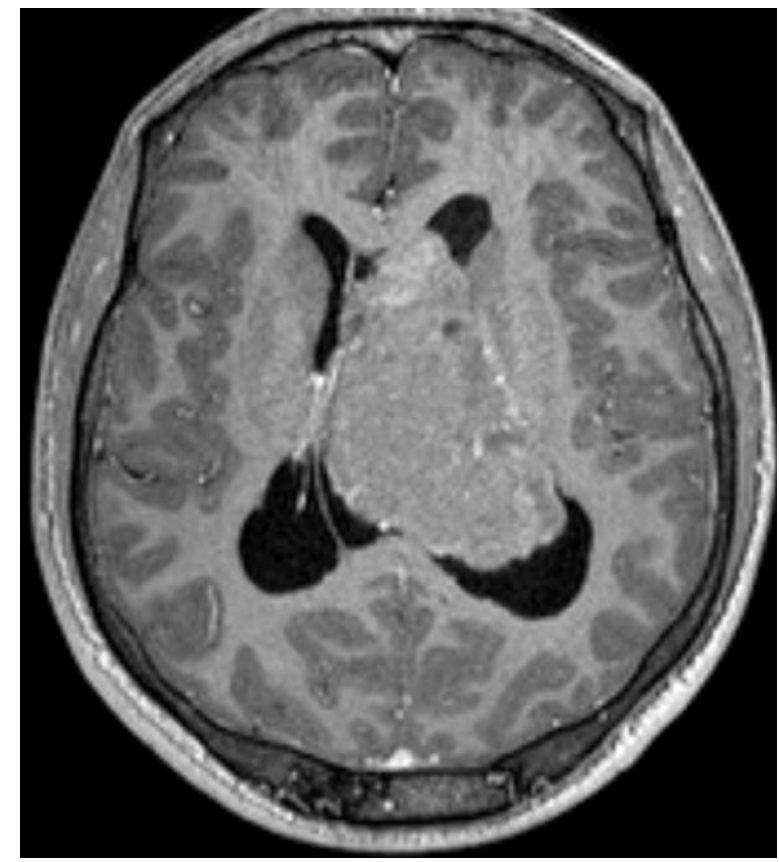

Figure2. Corresponding axial MR image of the same patient with $C N$

\section{DISCUSSION}

MRI is the imaging modality of choice for assessment of several intracranial pathologies. In addition to its utility for diagnosis of brain tumors, evaluation of treatment response, differentiation of recurrence and side effects of RT, detection and characterization of brain lesions with incorporation of functional imaging techniques, another important contribution of MRI is in target definition for precise radiation treatment planning.

Recent years have witnessed substantial improvements in the discipline of radiation oncology such as contemporary treatment strategies including Image Guided Radiation Therapy (IGRT), Adaptive Radiation Therapy (ART), Intensity Modulated Radiation Therapy (IMRT), Breathing Adapted Radiation Therapy (BART), and stereotactic irradiation with SRS, HFSRT, and SBRT [44-50].

Multimodality imaging may be utilized for improving the accuracy and precision of target delineation. Incorporation of combined use of fused CT and MR images may be utilized for supplementing each other to improve precision in delineation of target volumes for state of the art RT techniques. Usefulness of multimodality imaging for radiation treatment planning of CNs has been poorly addressed in the literature. In this context, our study may add to the existing body of literature by reporting improved target determination by incorporation of MRI in radiation treatment planning of CNs. Several other studies have also suggested a role for multimodality imaging in target volume definition for precision RT [51-62].

In conclusion, incorporation of MRI into radiation treatment planning of $\mathrm{CNs}$ may improve precision and accuracy in target definition, however, there is need for further studies.

\section{REFERENCES}

[1] Tish S, Habboub G, Jones J, Ostrom QT, Kruchko C, et al. (2019) The epidemiology of central and extra ventricular neurocytoma in the United States between 2006 and 2014.J Neurooncol. 143(1): 123-127.

[2] Dutta SW, Kaleem TA, Muller DA, Peterson J, Harrell AC, et al. (2018) Central neurocytoma: Clinical characteristics, patterns of care, and survival.J Clin Neurosci. 53: 106-111.

[3] Lee SJ, Bui TT, Chen CH, Lagman C, Chung LK, et al. (2016) Central Neurocytoma: A Review of Clinical Management and Histopathologic Features. Brain Tumor Res Treat. 4(2): 49-57.

[4] Khoo J, Tollesson G. (2020) Endoscopic approach and stereotactic radiosurgery for a posterior third ventricular Central Neurocytoma - case report and literature review.Int J Surg Case Rep. 68: 119-123.

[5] Javedan SP, Manwaring K, Smith KA. (2003) Treatment of posterior third ventricular central neurocytoma with endoscopic biopsy, endoscopic third ventriculostomy and stereotactic radiosurgery. Minim Invasive Neurosurg. 46(3): 165-8. 
[6] Wong J, Teo C, Kwok B. (2006) Central neurocytoma in third and fourth ventricles with aqueductal involvement. Br J Neurosurg. 20(1): 57-62.

[7] Park SJ, Jung TY, Kim SK, Lee KH. (2018)Tumor control of third ventricular central neurocytoma after gamma knife radio surgery in an elderly patient: A case report and literature review. Medicine (Baltimore). 97(50): e13657.

[8] Johnson MO, Kirkpatrick JP, Patel MP, Desjardins A, Randazzo DM, et al. (2019) The role of chemotherapy in the treatment of central neurocytoma.CNS Oncol. 8(3): CNS41.

[9] Kim JW, Kim DG, Kim IK, Kim YH, Choi SH, et al. (2013) Central neurocytoma: long-term outcomes of multimodal treatments and management strategies based on 30 years' experience in a single institute. Neurosurgery. 72(3): 407-13; discussion 413-4

[10] Thawani JP, Lee JY. (2015) The management of residual or recurrent central neurocytoma. Neurosurg Clin N Am. 26(1):67-81.

[11] Barani IJ, Raleigh DR, Larson D. (2015) The management of central neurocytoma: radiotherapy. Neurosurg Clin N Am.26(1):45-56.

[12] Monaco EA 3rd, Niranjan A, Lunsford LD. (2015) The management of central neurocytoma: radiosurgery. Neurosurg Clin N Am.26(1): 37-44.

[13] Garcia RM, Ivan ME, Oh T, Barani I, Parsa AT. (2014) Intraventricular neurocytomas: a systematic review of stereotactic radiosurgery and fractionated conventional radiotherapy for residual or recurrent tumors. Clin Neurol Neurosurg. 117: 55-64.

[14] Kim JW, Kim DG, Chung HT, Choi SH, Han $\mathrm{JH}$, et al. (2013) Radio surgery for central neurocytoma: long-term outcome and failure pattern. J Neurooncol. 115(3): 505-11.

[15] Karlsson B, Guo WY, Kejia T, Dinesh N, Pan $\mathrm{DH}$, et al. (2012) Gamma Knife surgery for central neurocytomas.J Neurosurg. 117 Suppl: 96-101.

[16] Cobery ST, Noren G, Friehs GM, Chougule P, Zheng Z, et al. (2001) Gamma knife surgery for treatment of central neurocytomas. Report of four cases. J Neurosurg. 2001Feb;94(2):327-30.

[17] Chen MC, Pan DH, Chung WY, Liu KD, Yen YS, et al. (2011) Gamma knife radio surgery for central neurocytoma: retrospective analysis of fourteen cases with a median follow-up period of sixty-five months. Stereotact Funct Neurosurg. 89(3): 185-93.

[18] Matsunaga S, Shuto T, Suenaga J, Inomori S, Fujino H. (2010) Gamma knife radio surgery for central neurocytomas. Neurol Med Chir (Tokyo). 2010; 50 (2):107-12; discussion 112-3.
[19] Yen CP, Sheehan J, Patterson G, Steiner L. (2007) Gamma knife surgery for neurocytoma.J Neurosurg. 2007 Jul; 107 (1):7-12.

[20] Kim CY, Paek SH, Jeong SS, Chung HT, Han JH, et al. (2007) Gamma knife radio surgery for central neurocytoma: primary and secondary treatment. Cancer. 110(10): 2276-84.

[21] Bertalanffy A, Roessler K, Dietrich W, Aichholzer M, Prayer D, et al. (2001)Gamma knife radio surgery of recurrent central neurocytomas: a preliminary report.J Neurol Neurosurg Psychiatry. 70(4): 489-93.

[22] Bertalanffy A, Roessler K, Koperek O, Gelpi E, Prayer D, Knosp E. (2005) Recurrent central neurocytomas.Cancer.104(1):135-142.

[23] Sirin S, Oysul K, Surenkok S, Sager O, Dincoglan F, et al. (2011) Linear acceleratorbased stereotactic radiosurgery in recurrent glioblastoma: A single center experience. Vojnosanit Pregl 68(11): 961-966.

[24] Dincoglan F, Sager O, Gamsiz H, Demiral S, Uysal B (2012) Management of arteriovenous malformations by stereotactic radiosurgery: A single center experience. UHOD-Uluslararasi Hematoloji-Onkoloji Dergisi 22: 107-112.

[25] Surenkok S, Sager O, Dincoglan F, Gamsiz H, Demiral S (2012) Stereotactic radio surgery in pituitary adenomas: A single center experience. UHOD-Uluslararasi Hematoloji- Onkoloji Dergisi 22: 255-260.

[26] Dincoglan F, Beyzadeoglu M, Sager O, Oysul K, Sirin S (2012) Image-guided positioning in intracranial non-invasive stereotactic radiosurgery for the treatment of brain metastasis. Tumori 98(5): 630-635.

[27] Dincoglan F, Sager O, Gamsiz H, Uysal B, Demiral S, et al. (2012) Stereotactic radiosurgery for intracranial tumors: A single center experience. Gulhane Med J 54(3): 190-198.

[28] Sager O, Beyzadeoglu M, Dincoglan F, Demiral S, Uysal B, et al. (2013) Management of vestibular schwannomas with linear accelerator-based stereotactic radio surgery: A single center experience. Tumori 99(5): 617-622.

[29] Demiral S, Beyzadeoglu M, Uysal B, Oysul K, Kahya YE, et al. (2013) Evaluation of stereotactic body radiotherapy (SBRT) boost in the management of endometrial cancer. Neoplasma 60(3): 322-327.

[30] Dincoglan F, Beyzadeoglu M, Sager O, Uysal B, Demiral S, et al. (2013) Evaluation of linear accelerator-based stereotactic radio surgery in the management of meningiomas: A single center experience. J BUON 18(3): 717-722.

[31] Sager O, Beyzadeoglu M, Dincoglan F, Uysal B, Gamsiz H, et al. (2014) Evaluation of linear accelerator (LINAC)-based stereotactic radiosurgery (SRS) for cerebral cavernous 
malformations: A 15-year single-center experience. Ann Saudi Med 34(1): 54-58.

[32] Sager O, Beyzadeoglu M, Dincoglan F, Gamsiz H, Demiral S, et al. (2014) Evaluation of linear accelerator-based stereotactic radio surgery in the management of glomus jugulare tumors. Tumori 100(2): 184-188.

[33] Sager O, Dincoglan F, Beyzadeoglu M (2015) Stereotactic radiosurgery of glomus jugulare tumors: Current concepts, recent advances and future perspectives. CNS Oncol 4(2): 105-114.

[34] Gamsiz H, Beyzadeoglu M, Sager O, Dincoglan F, Demiral S, et al. (2014) Management of pulmonary oligometastases by stereotactic body radiotherapy. Tumori 100(2): 179-183.

[35] Dincoglan F, Sager O, Gamsiz H, Uysal B, Demiral S, et al. (2014) Management of patients with $\geq 4$ brain metastases using stereotactic radiosurgery boost after whole brain irradiation. Tumori 100(3): 302-306.

[36] Demiral S, Beyzadeoglu M, Sager O, Dincoglan F, Gamsiz H, et al. (2014) Evaluation of linear accelerator (linac)-based stereotactic radiosurgery (srs) for the treatment of craniopharyngiomas. UHOD - Uluslararasi Hematoloji- Onkoloji Dergisi 24: 123-129.

[37] Gamsiz H, Beyzadeoglu M, Sager O, Demiral S, Dincoglan F, et al. (2015) Evaluation of stereotactic body radiation therapy in the management of adrenal metastases from nonsmall cell lung cancer. Tumori 101(1): 98-103.

[38] Dincoglan F, Beyzadeoglu M, Sager O, Demiral S, Gamsiz H, et al. (2015) Management of patients with recurrent glioblastoma using hypofractionated stereotactic radiotherapy. Tumori 101(2): 179-184.

[39] Demiral S, Dincoglan F, Sager O, Gamsiz H, Uysal B, et al. (2016) Hypo fractionated stereotactic radiotherapy (HFSRT) for who grade I anterior clinoid meningiomas (ACM). Jpn J Radiol 34(11): 730-737.

[40] Dincoglan F, Sager O, Demiral S, Uysal B, Gamsiz H, et al. (2017) Radiosurgery for recurrent glioblastoma: A review article. Neurol Disord Therap 1: 1-5.

[41] Demiral S, Dincoglan F, Sager O, Uysal B, Gamsiz H, et al. (2018) Contemporary Management of Meningiomas with Radiosurgery. Int J Radiol Imaging Technol 80(2): 187-190.

[42] Dincoglan F, Sager O, Demiral S, Gamsiz H, Uysal B, et al. (2019) Fractionated stereotactic radiosurgery for locally recurrent brain metastases after failed stereotactic radiosurgery. Indian J Cancer 56(2):151-156.

[43] Dincoglan F, Sager O, Uysal B, Demiral S, Gamsiz H, et al. (2019) Evaluation of hypofractionated stereotactic radiotherapy
(HFSRT) to the resection cavity after surgical resection of brain metastases: A single center experience.Indian J Cancer 56(3):202-206.

[44] Sager O, Beyzadeoglu M, Dincoglan F, Oysul K, Kahya YE, et al. (2012) Evaluation of active breathing control-moderate deep inspiration breath-hold in definitive non-small cell lung cancer radiotherapy.Neoplasma 59(3): 333-340.

[45] Dincoglan F, Beyzadeoglu M, Sager O, Oysul K, Kahya YE, et al. (2013) Dosimetric evaluation of critical organs at risk in mastectomized leftsided breast cancer radiotherapy using breath-hold technique. Tumori 99(1): 76-82.

[46] Uysal B, Beyzadeoğlu M, Sager O, Dinçoğlan F, Demiral S, et al. (2013) Dosimetric evaluation of intensity modulated radiotherapy and 4-field 3-d conformal radiotherapy in prostate cancer treatment.Balkan Med J 30(1): 54-57.

[47] Sager O, Beyzadeoglu M, Dincoglan F, Demiral S, Uysal B, et al. (2015) Adaptive splenic radiotherapy for symptomatic splenomegaly management in myeloproliferative disorders. Tumori 101(1): 84-90.

[48] Sager O, Dincoglan F, Uysal B, Demiral S, Gamsiz H, et al. (2017) Splenic Irradiation: A Concise Review of the Literature. J App Hem B1 Tran 1(1): 101.

[49] Sager O, Dincoglan F, Uysal B, Demiral S, Gamsiz H, et al. (2018) Evaluation of adaptive radiotherapy (ART) by use of replanning the tumor bed boost with repeated computed tomography (CT) simulation after whole breast irradiation (WBI) for breast cancer patients having clinically evident seroma.Jpn J Radiol 36(6): 401-406.

[50] Sager O, Dincoglan F, Demiral S, Uysal B, Gamsiz H, et al. (2019) Breathing adapted radiation therapy for leukemia relapse in the breast: A case report.World J Clin Oncol 10(11): 369-374.

[51] Dincoglan F, Sager O, Demiral S, Beyzadeoglu M. (2019) Incorporation of Multimodality Imaging in Radiosurgery Planning for Craniopharyngiomas: An Original Article. SAJ Cancer Sci 6: 103.

[52] Demiral S, Sager O, Dincoglan F, Beyzadeoglu M. (2019) Assessment of Computed Tomography (CT) And Magnetic Resonance Imaging (MRI) Based Radiosurgery Treatment Planning for Pituitary Adenomas. Canc Therapy \& Oncol Int J 13(2): 555857.

[53] Beyzadeoglu M, Sager O, Dincoglan F, Demiral S. (2019) Evaluation of Target Definition for Stereotactic Reirradiation of Recurrent Glioblastoma. Arch Can Res 7(1): 3.

[54] Sager O, Dincoglan F, Demiral S, Beyzadeoglu M. (2019) Evaluation of Radiosurgery Target Volume Determination for Meningiomas Based 
Target Volume Determination for Precise Radiation Therapy (RT) of Central Neurocytoma: An Original Article

on Computed Tomography (CT) And Magnetic Resonance Imaging (MRI) Cancer Sci Res Open Access 5(2): 1-4.

[55] Dincoglan F, Sager O, Demiral S, Beyzadeoglu M. (2019) Multimodality Imaging for Radiosurgical Management of Arteriovenous Malformations. Asian Journal of Pharmacy, Nursing and Medical Sciences7(1): 7-12.

[56] Demiral S, Sager O, Dincoglan F, Beyzadeoglu M. Assessment of target definition based on Multimodality imaging for radiosurgical Management of glomus jugulare tumors (GJTs). Cancer Ther Oncol Int J 15(2): 555909.

[57] Sager O, Dincoglan F, Demiral S, Gamsiz H, Uysal B, et al. (2019) Evaluation of the Impact of Magnetic Resonance Imaging (MRI) on Gross Tumor Volume (GTV) Definition for Radiation Treatment Planning (RTP) of Inoperable High Grade Gliomas (HGGs). Concepts in Magnetic Resonance Part A Volume 2019, Article ID 4282754.

[58] Sager O, Dincoglan F, Demiral S, Gamsiz H, Uysal B, et al. (2019) Utility of Magnetic Resonance Imaging (Imaging) in Target
Volume Definition for Radiosurgery of Acoustic Neuromas. Int J Cancer Clin Res 6: 119.

[59] Demiral S, Sager O, Dincoglan F, Uysal B, Gamsiz H, et al. (2018) Evaluation of Target Volume Determination for Single Session Stereotactic Radiosurgery (SRS) of Brain Metastases. Canc Therapy \& Oncol Int J 12(5): 555848 .

[60] Sager O, Demiral S, Dincoglan F, Beyzadeoglu M. (2020) Target Volume Definition for Stereotactic Radiosurgery (SRS) Of Cerebral Cavernous Malformations (CCMs). Canc Therapy \& Oncol Int J 15(4): 555917.

[61] Dincoglan F, Demiral S, Sager O, Beyzadeoglu M. (2020) Utility of Multimodality Imaging Based Target Volume Definition for Radiosurgery of Trigeminal Neuralgia: An Original Article. Biomed J Sci \& Tech Res26 (2) : 19728-19732.

[62] Beyzadeoglu M, Dincoglan F, Sager O, Demiral S. (2020) Evaluation of Target Volume Definition with Multimodality Imaging for Radiosurgery of Intracranial Germ Cell Tumors (GCTs): An Original Article. Asian Journal of Pharmacy, Nursing and Medical Sciences 08(02), 1-4.

Citation: Murat Beyzadeoglu et.al, "Target Volume Determination for Precise Radiation Therapy (RT) of Central Neurocytoma: An Original Article”, International Journal of Research Studies in Medical and Health Sciences. 2020; 5(3): 29-34.

Copyright: (C) 2020 Murat Beyzadeoglu et.al, This is an open-access article distributed under the terms of the Creative Commons Attribution License, which permits unrestricted use, distribution, and reproduction in any medium, provided the original author and source are credited. 